\title{
PACIENTŲ KELIO FUNKCIJOS VERTINIMAS PO KELIO SĄNARIO ENDOPROTEZAVIMO OPERACIJOS. PALYGINIMAS TARP DVIEJŲ ŠALIŲ
}

\author{
Algimantas Čebatoriuss, , ${ }^{1,}$ Kazimieras Grigaitis³, Justinas Stučinskas³, \\ Daiva Mockevičiené ${ }^{2}$, Augustas Česnavičius ${ }^{4}$ \\ ${ }^{1}$ Klaipèdos universitetinés ligoninès Traumatologijos departamentas, Traumatologijos skyrius, \\ ${ }^{2}$ Klaipedos universiteto Sveikatos mokslu fakultetas, Reabilitacijos katedra, \\ ${ }^{3}$ Lietuvos sveikatos mokslu universiteto ligoninè Kauno klinikos, \\ Ortopedijos traumatologijos klinika, ${ }^{4}$ Lietuvos sveikatos mokslu universitetas
}

Raktažodžiai: PROMs, totalinis kelio sąnario endoprotezavimas, KOOS.

\begin{abstract}
Santrauka
Ivadas. Kelio sąnario endoprotezavimo operacija pagerina paciento kelio sąnario funkciją. Pacientai objektyviai tai gali ịvertinti naudodami pacientų savęs vertinimo klausimynus (PROMs). Šio tyrimo metu buvo siekiama palyginti kelio sąnario funkciją po kelio sąnario endoprotezavimo dviejose skirtingo socioekonominio lygio šalyse: Lietuvoje ir Švedijoje. Metodai. Tyrime dalyvavo pacientai iš Lietuvos ir Švedijos, kuriems 2013 metais buvo atliekama kelio sąnario endoprotezavimo operacija dèl osteoartrozès. Iki operacijos buvo vertinama demografiniai rodikliai bei kelio sąnario funkcija. Kelio sąnario funkcijai vertinti buvo naudojamas klausimynas "Knee injury and Osteoarthritis Outcome Score" (KOOS).

Rezultatai. Itraukti 527 Švedijos pacientai ir 159 Lietuvos pacientai. Po 1 metų susisiekta su 445 Švedijos pacientais ir 86 Lietuvos pacientais. Vertinant KOOS klausimyno rezultatus reikšmingo skirtumo nebuvo matoma.

Išvados. Kelio sąnario funkcija iki protezavimo operacijos Lietuvoje ir Švedijoje buvo panaši, nustatytas tolygus pagerèjimas praejjus 1 metams po endoprotezavimo operacijos.
\end{abstract}

\section{Ivadas}

Siekant objektyviai įvertinti paciento kelio sąnario funkcijos pagerèjimą vis dažniau naudojami paciento savęs vertinimo klausimynai (PROMs). Šiais klausimynais galima vertinti pacientų gyvenimo kokybės pagerèjimo rezultatus.

PROMs gali būt naudojami priimant sprendimus, vertinančius sveikatos sistemos darbą. Taip pat gali būti vertinami ligoniniu gydymo rezultatai, pagal kuriuos pacientas galètų pasirinkti gydymo ịstaigą [1]. Toks funkcinių rezultatų vertinimas jau atliktas tarp kelių šalių (UK, US, Australija, Švedija, Kanada) [2-4]. Tyrime lyginamos dvi Europos Sąjungos šalys, kurios priklauso skirtingam soceoekonominiam lygiui ("Global Wellbeing Index" Švedija 4-ta vieta, Lietuva 66-ta). [5] Lyginami pacientų demografiniai rodikliai ir kelio funkcijos rezultatai pagal KOOS klausimyną.

Darbo tikslas: palyginti dviejų skirtingo socioekonominio statuso šaliu pacientų, kelio sąnario funkcijos rezultatus po totalinio kelio sąnario endoprotezavimo

\section{Metodai}

I tyrimą įtraukti pacientai, kuriems 2013 metais buvo atliekamas pirminis kelio sąnario endoprotezavimas dèl OA Lietuvoje ir Švedijoje. I Švedijos kohortą buvo traukiami pacientai iš vieno centro, kuriame pacientai KOOS klasimyną užpildo 2-6 sav. iki operacijos. Lietuvoje duomenys buvo renkami iš 8 skirtingų endoprotezavimą atliekančių centrų. Pacientai anketą pildydavo dieną prieš operaciją.

Kelio sąnario funkcija vertinta pagal "Knee injury and Osteoarthritis Outcome Score" (KOOS). KOOS klausimynas išskaidytas ị 5 dalis: skausmas; simptomai; judrumas, kasdienis gyvenimas; judrumas, sportas ir rekreacinè veikla; gyvenimo kokybè. Pildydamas anketą, pacientas kelio sąnario funkciją vertina paskutinę savaitę. Kiekvienas klausymas turi 5 standartinius atsakymus, kurie vertinami nuo 0 iki 4 balų. Kiekvienai grupei apskaičiuojamas normalizuotas balas nuo 0 iki 100, kur 100 - paciento kelio sąnario funkcija gera, jis nejaučia jokių simptomų ir 0 -kelio sąnario simptomai 
maksimaliai apsunkina paciento kelio sąnario funkciją ir gyvenimą. Tyrime buvo naudotos validizuotos abiejų šalių klausimyno formos $[6,7]$.

Statistika. Nuolatiniams kintamiesiems aprašyti buvo naudojami vidurkiai, standartiniai nuokrypiai (SN) ir skaičiai bei procentai - kategoriniams kintamiesiems. Grupių palyginimui naudotas Welsh t-testas. Chi kvadrato testas naudotas kategorinių duomenų palyginimui. Statistiškai reikšmingas

\begin{tabular}{|c|c|}
\hline Švedija & Lietuva \\
\hline $\begin{array}{c}567 \text { pacientai atitikę ịtraukimo } \\
\text { i tyrimą kriterijus }\end{array}$ & $\begin{array}{c}159 \text { pacientai atitikę įtraukimo } \\
\text { į tyrimą kriterijus }\end{array}$ \\
\hline $\begin{array}{l}527 \text { (93 proc.) pacientai užpildę } \\
\text { klausimynus iki operacijos }\end{array}$ & $\begin{array}{l}159 \text { (100 proc.) pacientai užpildę } \\
\text { klausimynus iki operacijos }\end{array}$ \\
\hline $\begin{array}{l}445 \text { ( } 78 \text { proc.) pacientai užpildę } \\
\text { klausimynus iki ir po operacijos }\end{array}$ & $\begin{array}{l}86 \text { (54 proc.) pacientai užpildę } \\
\text { klausimynus iki ir po operacijos }\end{array}$ \\
\hline
\end{tabular}

1 pav. Lietuvos ir Švedijos pacientų tiriamosios grupès.

1 lentelè. Lietuvos ir Švedijos pacientų duomenų iki operacijos palyginimas.

* Kliniškai ir statistiškai reikšmingas skirtumas

\begin{tabular}{|l|c|c|c|}
\hline & $\begin{array}{c}\text { Lietuva } \\
\mathbf{n = 1 5 9}\end{array}$ & $\begin{array}{c}\text { Švedija } \\
\mathbf{n = 5 2 7}\end{array}$ & p reikšme் \\
\hline Vyrai / Moterys & & & \\
\hline $\mathbf{n}$ & $35 / 124$ & $206 / 321$ & $<0.0001^{*}$ \\
\hline Amžius & $22 / 78$ & $39 / 61$ & \\
\hline Vidurkis (SN) & $69.1(9.3)$ & $68.9(8.9)$ & 0.8 \\
\hline Mediana & 71 & 69 & \\
\hline KMI kg/m 2 & $\mathrm{n}=152$ & $\mathrm{n}=508$ & \\
\hline Vidurkis (SN) & $31.3(6.1)$ & $29(4.4)$ & $<0.0001^{*}$ \\
\hline Mediana & 31 & 28.6 & \\
\hline ASA klasė n (\%) & $\mathrm{n}=105$ & $\mathrm{n}=510$ & \\
\hline ASA I & $17(16.2)$ & $102(20)$ & $<0.0001^{*}$ \\
\hline ASA II & $63(60)$ & $374(73.3)$ & \\
\hline ASA III & $24(22.9)$ & $34(6.7)$ & \\
\hline ASA IV & $1(0.9)$ & $0(0)$ & \\
\hline KOOS Skausmas & $43(16)$ & $42(15)$ & 0.6 \\
\hline KOOS Simptomai & $50(19)$ & $49(18)$ & 0.4 \\
\hline $\begin{array}{l}\text { KOOS Kasdiene் } \\
\text { veikla }\end{array}$ & $43(15)$ & $48(16)$ & $<0.0001$ \\
\hline KOOS Sportas/ \\
Reak. & $26(21)$ & $12(15)$ & $<0.0001^{*}$ \\
\hline KOOS Gyv. ko- & $33(16)$ & $25(15)$ & $<0.0001^{*}$ \\
\hline kybe் & & & \\
\hline
\end{tabular}

skirtumas buvo laikomas, kai $\mathrm{p}<0.05$. Didesnis arba 8 balų skirtumas buvo laikomas kliniškai reikšmingu skirtumu vertinat KOOS klausimyną [8].

\section{Rezultatai}

I tyrimą įtraukti 159 Lietuvos pacientai ir 527 Švedijos pacientai. Po vienerių metų klausimynas pakartotinai buvo užpildytas 445 Švedijos pacientų ir 86 Lietuvos pacientuc (1 paveikslas). TKE pacientai. Lietuvos pacientų grupejje daugiau moteriškos lyties pacientų, stebėtas didesnis KMI ir ASA klasè. (1 lentelè). Vertinant kelio sąnario funkciją geresni Lietuvos pacientų rezultatai stebėti sporto/reakreaciniame ir gyvenimo kokybès pogrupiuose (1 lentelè).

Praejjus vieneriems metams po operacijos, reikšmingai geresni rezultatai liko tik vertinant judrumą esant padidejusiam fiziniam aktyvumui, o lyginant kitas būsenas skirtumų nepastebèta (2 lentelè).

\section{Diskusija}

Studija tyrẻ pacientus, kuriems buvo atlikta kelio sąnario endoprotezavimo operacija dviejose skirtingo socialinio ir ekonominio statuso šalyse, kuriose skiriasi medicinos pagalbos lygis, atvejų skaičius bei patirtis. Tačiau skirtumas tarp šalių nebuvo toks didelis, kaip tikejjomès. Tikètina, kad tokie rezultatai gali būti stebimi, nes pacientai klausimynus pildè skirtingu metu iki operacijos. Labiau tikètina, kad rezultatai priklausé nuo paciento bendros sveiktos būklès, o ne kelio sąnario funkcijos. Pooperaciniu laikotarpiu Lietuvos pacientai savo funkciją vertino didesnio aktyvumo grupejje. Galima spélioti, kad tokie rezultatai buvo paveikti skirtingu pacientų lūkesčiu skirtingose šalyse. Mūsų tyrimo rezultatai nesutampa su kitų tyrimų rezultatais. Kitose studijose Lietuvoje žmonès savo gyvenimo kokybę vertina prasčiau nei

2 lentelè. KOOS prieš ir vieneri metai po operacijos.

* Kliniškai ir statistiškai reikšmingas skirtumas

\begin{tabular}{|l|c|c|c|}
\hline & $\begin{array}{c}\text { Lietuva } \\
\mathbf{n}=\mathbf{8 6}\end{array}$ & $\begin{array}{c}\text { Švedija } \\
\mathbf{n}=\mathbf{4 4 5}\end{array}$ & p reikšmė \\
\hline KOOS Skausmas & $46(15)$ & $43(15)$ & 0.1 \\
\hline KOOS Simptomai & $53(18)$ & $49(17)$ & 0.05 \\
\hline KOOS Kasdienė veikla & $46(14)$ & $49(15)$ & 0.06 \\
\hline KOOS Sportas/Reak. & $31(23)$ & $13(14)$ & $<0.0001^{*}$ \\
\hline KOOS Gyv. kokybė & $33(18)$ & $25(15)$ & $<0.0001^{*}$ \\
\hline KOOS Skausmas 1 m. & $81(17)$ & $78(19)$ & 0.2 \\
\hline KOOS Simptomai $1 \mathrm{~m}$. & $77(19)$ & $74(18)$ & 0.2 \\
\hline KOOS Kasdienė veikla $1 \mathrm{~m}$. & $80(18)$ & $77(19)$ & 0.2 \\
\hline KOOS Sportas/Reak. $1 \mathrm{~m}$. & $60(24)$ & $35(26)$ & $<0.0001^{*}$ \\
\hline KOOS Gyv. kokybė $1 \mathrm{~m}$. & $60(24)$ & $63(24)$ & 0.5 \\
\hline
\end{tabular}


Švedijoje. [9] Galime teigti, kad gyvenimo kokybės pokyčio po gydymo vertinimas tarp dviejų skirtingų šalių neturètų ribotis tik PROMs klausimynais, nes klausimynų pildymas gali dažnai būti sudètingas, o pacientai negali efektyviai ivertinti tam tikros srities funkcijos.

\section{Išvada}

Kelio sąnario funkcija iki protezavimo operacijos Lietuvoje ir Švedijoje buvo panaši bei nustatytas tolygus pagerejimas praejus 1 metams po endoprotezavimo operacijos.

\section{Literatūra}

1. Devlin NJ, Appleby J, King's Fund Centre (London England), Buxton M, Office of Health Economics (London England): Getting the most out of PROMs : putting health outcomes at the heart of NHS decision-making. London. King's Fund, 2010.

2. Fortin PR, Clarke AE, Joseph L, Liang MH, Tanzer M, Ferland D, Phillips C, Partridge AJ, Belisle P, Fossel AH. et al: Outcomes of total hip and knee replacement: preoperative functional status predicts outcomes at six months after surgery. Arthritis and Rheumatism 1999; 42(8):1722-1728.

https://doi.org/10.1002/1529-0131(199908)42:8<1722::AIDANR22 $>3$.0.CO;2-R

3. Lingard EA, Sledge CB, Learmonth ID: Patient expectations regarding total knee arthroplasty: differences among the United States, United Kingdom, and Australia. The Journal of Bone and Joint Surgery American Volume 2006; 88(6):1201-1207.

4. Ackerman IN, Dieppe PA, March LM, Roos EM, Nilsdotter AK, Brown GC, Sloan KE, Osborne RH: Variation in age and physical status prior to total knee and hip replacement surgery: a comparison of centers in Australia and Europe. Arthritis and Rheumatism 2009; 61(2):166-173.

https://doi.org/10.1002/art.24215

5. Countries of the world [http://geographic.org/country_ranks/ global_wellbeing_index_2010_country_ranks.html]

6. Knee injury and Osteoarthritis Outcome Score [http://koos.nu]

7. EQ-5D [http://www.euroqol.org/]

8. Roos EM, Lohmander LS: The knee injury and osteoarthritis outcome score (KOOS): from joint injury to osteoarthritis.
Health and Quality of Life Outcomes 2003; 1:64.

https://doi.org/10.1186/1477-7525-1-64

9. Molzahn AE, Kalfoss M, Schick Makaroff K, Skevington SM: Comparing the importance of different aspects of quality of life to older adults across diverse cultures. Age and Ageing 2011; 40(2):192-199.

https://oi.org/10.1093/ageing/afq156

\section{EVALUATION KNEE FUNCTION AFTER TOTAL KNEE ARTHROPLASTY. COMPARISON BETWEEN TWO COUNTRIES \\ A.Čebatorius, K.Grigaitis, J.Stučinskas, D.Mockevičienė, A.Česnavičius}

Key words: PROMs, total knee replacement, KOOS.

Summary

Introduction. The knee replacement surgery significantly improves the patient's knee joint function. The patient can evaluate this by using objective patient self-assessment questionnaires (PROMs). The aim of this study was to compare the knee function after knee replacement in two different socio-economic levels countries.

Methods. The study included patients from Lithuania and Sweden who underwent knee arthroplasty surgery s in 2013. Before the operation function of the knee were evaluated. Knee injury and Osteoarthritis Outcome Score (KOOS) was used to assess knee function.

Results. 527 Swedish patients and 159 Lithuanian patients were included. After 1 year contacted 445 Swedish patients and $86 \mathrm{Li}$ thuanian patients. There was no significant difference in the results of the KOOS questionnaire.

Conclusions. The knee function before prosthetic surgery in Lithuania and Sweden was similar and a steady improvement was seen 1 year after the endoprosthesis surgery.

Correspondence to: a.cebatorius@gmail.com

Gauta 2018-11-26 